\title{
The state of our prisons and what this reveals about our society
}

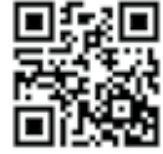

In the third decade of a new South Africa (SA), major challenges are being faced in almost every aspect of life, ranging from meeting minimum daily subsistence requirements, through providing education and primary healthcare, to the functioning of our legal system and governance at local and national levels. While in this context levels of crime and corruption are reaching new heights, we should not lose sight of the need for humane and accountable approaches to crime and imprisonment. The 37th anniversary on 12 September of Steve Biko's death under inhumane conditions and without adequate medical care in prison provides an opportunity to remember past failings and to reconsider the lessons these hold for our society.

In the Steve Biko era, medical care for prisoners was provided through the District Surgeon Services under the control of the Department of Health. Failure to treat Steve Biko adequately was explained by the breakdown in professional ethical behaviour of the district surgeons, who succumbed to pressure from the Special Branch of the Security Police. Their personal professional defaults were paralleled by failure of health professional bodies to act appropriately.

In 1994, Divisions of Human Rights Watch published a report on conditions in SA prisons. ${ }^{[1]}$ Much attention was correctly devoted to emphasising the ethical responsibilities of doctors in caring for prisoners and detainees and to exhorting the medical profession to meet its self-proclaimed standards. ${ }^{[1]}$ Since 1994, the Health Professions Council of South Africa has encouraged medical educators to promote knowledge of professional responsibilities generally and of responsibilities to prisoners specifically. ${ }^{[2]}$

In 1995, contrary to what would have seemed most appropriate, the National Department of Health began to dismantle the District Surgeon Services. It became possible for the Department of Correctional Services to appoint nurses and other medical staff to deliver healthcare in SA prisons (see, for example, advertisements for jobs in the Department of Correctional Services $\left.{ }^{[3]}\right)$. The rights of prisoners to healthcare have been spelled out in some detail, ${ }^{[4]}$ but it is doubtful whether these rights are remotely met. The retrogressive step of diverting some responsibilities for healthcare away from the Department of Health towards the Department of Correctional Services made it possible to dilute the loyalty of some health professionals to their patients by ranking allegiance to prison authorities higher than professional responsibility to patients. Not surprisingly, this is associated with greater reluctance of health professionals to work in prisons and has the potential to subvert the primary role of healers. In comparison, it should be noted that there were beneficial effects in 2006 when prison healthcare services in England and Wales were transferred into the National Health Service. ${ }^{[5]}$

Health services in the public sector have in general deteriorated over recent years, and such deterioration in our prisons has been documented in official reports from the Judicial Inspectorate of Prisons (Annual Reports of Prisons and Prisoners). Conditions under which prisoners are held became more unhygienic and inhumane as occupancy rates increased from $121 \%$ in 1995 to $161 \%$ in 2002 . Since then the occupancy rate was reduced to $144 \%$ in 2008 (with a range of occupancy rates of $100 \%$ to over $200 \%$ across correctional facilities in the country), but conditions remain far from adequate. The annual death rate in our prisons increased from 1.65/1 000 prisoners in 1995 to $9.1 / 1000$ in 2004 , but then fell to 6.4/1 000 in 2008. At the end of March 2009, SA correctional centres held a total of 165230 inmates. It was recently reported that the Minister of Justice and Correctional Services had announced that through a strategy to diminish overcrowding, the prison population in SA was reduced from 187006 in 2004 to 157170 by end of March 2014. ${ }^{[6]}$

SA's overcrowded, poorly ventilated prisons house 40000 more inmates than they should, and at least ten prisons have over $200 \%$ occupancy. Pollsmoor Prison in Cape Town holds 4162 prisoners (238\% occupation), with $60-80$ awaiting trial. ${ }^{[7]}$ Our prisons have been described as 'melting pots' for tuberculosis (TB) infection, with TB the most common cause of death among prisoners. Prisons are also notorious for being sites where multidrug-resistant (MDR) TB flourishes, and MDR TB is on the rise in SA. Crime is related to poverty, and the disparities in wealth in SA are among the widest in the world. The adverse effects of links between poverty and crime are exacerbated by the links between poverty and TB. ${ }^{[8]}$

As noted in the 2008 Annual Reports of Prisons and Prisoners, ${ }^{[9]}$ 'At most of these overcrowded facilities, there are few, if any, appropriate rehabilitation programmes and extremely limited recreational or work opportunities, in the form of gardening, farming, workshops or factories, available to inmates.' The majority of prisoners spend up to 23 hours per day in their cells, each in a space smaller than a single mattress, with limited toilet and ablution facilities and in generally unhygienic conditions. The report goes on to note that 'this constitutes an extremely unsatisfactory, and indeed unacceptable, environment for the care and development of offenders whom the Department has undertaken to rehabilitate and reintegrate into the community. The 2012/2013 Annual Report ${ }^{[10]}$ notes that as a result of poor prison conditions inmates are becoming increasingly frustrated, which, together with gangsterism, has resulted in several uprisings.

It is generally agreed that crime is a major problem in SA (as in many other societies) and that the prison system serves an essential social function. If, however, the system is abusive towards those who are incarcerated, often the most vulnerable in society, this should be considered unacceptable. It is arguable from experience in other countries that crime and imprisonment are of greater cost to society if rates and duration of imprisonment are increased (inmates serving a sentence in excess of 5 years increased from $49 \%$ in 1998 to $67 \%$ in 2008/2009), delays in trials are increased (30\% of inmates are still awaiting trial), and rehabilitation is ignored.

The system of inspection by the Inspecting Judge in SA is clearly beneficial and the annual reports provide analysis and reporting of conditions and statistics, with appropriate noting of severe shortcomings. Inadequate medical care was a critical factor in Steve Biko's death, and we need to ask why in our current democracy, even with recognition of the complexity of the challenges facing healthcare in the public sector, prison healthcare services have declined in quality rather than improved. It should be conceded that after considerable advocacy, more effort has been made to provide effective medications for TB and HIV/AIDS, both of which are infectious and eminently treatable. However, only nurses with primary healthcare experience are permitted to give antiretroviral treatment, and these comprise less than $25 \%$ of a total of 800 professional nurses in the employ of Correctional Services. On any given day it has been noted that there are 21000 inmates who are HIV-positive, yet less than half of the country's HIV-positive inmates receive antiretroviral treatment. ${ }^{[1]}$

The present reality of continued mistreatment of prisoners by authorities who are meant to protect them could perhaps be changed if the medical profession would work through appropriate channels 
to influence Correctional Services to improve medical care and rehabilitation. From 2006 to 2008, attempts were made by a small group of health professionals at the University of Cape Town to engage in such an effort with the support of Judge Fagan, then Judge of Prisons. The South African Medical Association (SAMA) was persuaded that its intervention as an influential medical body could effect some changes. Arrangements were made for representatives of the small group concerned, together with senior members of SAMA, to meet with the Minister of Correctional Services and his representatives. At two meetings reassurances were given that these issues would receive significant attention. Regrettably, and despite many subsequent communications with SAMA, this agenda has not been pursued.

The Africa Watch Prison Project group was approached to repeat its previous study, but also failed to respond. Several other international organisations that were incensed about conditions in our prisons during the apartheid era are seemingly no longer interested - perhaps because there has been a reduction in respect for civil rights and healthcare rights of prisoners in their own societies, as exemplified by continuing detention without trial and brutalising forced-feeding at Guantanamo Bay, ${ }^{[12]}$ and the recent reports of violence and brutality on Rikers Island. ${ }^{[13,14]} \mathrm{A}$ report from the Institute of Medicine reveals the involvement of US physicians in torture. ${ }^{[15]}$ It is notable from the 2010/2011 Correctional Services Report ${ }^{[13]}$ that torture (only electric shock treatment is specified) in SA prisons continues (and, like unnatural deaths, may even have increased), despite our country's ratification of the United Nations agreement on torture. In addition, it was noted that the absence of mental healthcare in prisons is associated with suicide. ${ }^{[16]}$

Despite recent investigations by the SA Human Rights Commission at the Groenpunt Prison, conditions in our prisons have not had a significant public profile. ${ }^{[17]}$ In relation to health and human dignity in our prisons and to recently exposed excesses of police brutality, ${ }^{[18]}$ our society has at best become inattentive and at worst complacent. Helen Zille, who exposed Biko's death when she was a journalist, notes a striking commonality between the SA at the time of Biko's death in 1977 and the SA of today. ${ }^{[19]}$

As noted almost a decade ago in the columns of this journal: '... the whole correctional service process, from police to judicial system to prisons, provides an image of the social and psychological health of our society. ${ }^{[20]}$ If the way a country treats prisoners, and those not yet convicted of crimes, is a measure of its civilisation and a marker of its vigilance over professional activities, we must surely be found wanting in our responses to crime and the responsibilities of our correctional services. These shortcomings mirror many other failures, now increasingly well documented, in a society with the potential and aspiration to do so much better. ${ }^{[21]}$

\section{Solomon Benatar}

Bioethics Centre, University of Cape Town, South Africa, and Joint Centre for Bioethics, University of Toronto, Canada

Corresponding author: S Benatar (solomon.benatar@uct.ac.za)

1. Africa Watch Prison Project, Divisions of Human Rights Watch. Prison Conditions in South Africa. New York: Human Rights Watch, 1994

2. Health Professions Council of South Africa: Ethics Rules and Regulations. http://www.hpcsa.co.za/ conduct_rules.php (accessed 21 February 2014)

3. Job Vacancies Department of Correctional Services. http://www.dcs.gov.za/Vacancies/DCS\%20 AD2.20102011.pdf (accessed 25 July 2014).

4. Muntingh L. Prisons in a democratic South Africa - a guide to the rights of prisoners as described in the Correctional Services Act and Regulations. Cape Town, 2006. http://cspri.org.za/publications/ research-reports/Prisons\%20in\%20a\%20Democratic\%20South\%20Africa\%20-\%20a\%20Guide\%20 to $\% 20$ the $\% 20$ Rights $\% 20$ of $\% 20$ Prisoners\%20as\%20Described $\% 20$ in $\% 20$ the $\% 20$ Correctional $\% 20$ Services\%20Act\%20and\%20Regulations.pdf (accessed 14 July 2014).

5. Hayton, P, Boyington J. Prisons and health reforms in England and Wales. Am J Public Health 2006;96(10):1730-1733. [http://dx. doi.org/10.2105/AJPH.2004.056127]

6. People's Assembly. MPs address overcrowding in prisons, parole hearings and state of correctional facilities. http://www.pa.org.za/blog/mps-address-overcrowding-prisons-parole-hearings-a (accessed 25 July 2014).

7. Wood R. Right to care in South Africa. 2012. https://www.facebook.com/rtcsa/posts/234287843340645 (accessed 14 July 2014).
(a)

8. Benatar SR, Upshur R. Tuberculosis and structural poverty: What can be done? C 3 Conference on Strategies to Overcome Poverty \& Inequality, Cape Town, 3 - 7 September 2012. http://www.carnegie3. org.za/docs/papers/20_Benatar_Tubercolosis\%20and\%20structural\%20poverty\%20-\%20what $\% 20$ can\%20be\%20done.pdf (accessed 14 July 2014).

9. Annual Reports of Prisons and Prisoners 2008. Civil society prisons reform initiative. http://cspri.org. $\mathrm{za}$ /resources/other-resources (accessed 26 January 2014).

10. Judicial Inspectorate for Correctional Services. Annual Report for 2012/2013. http://judicialinsp.dcs. gov.za/Annualreports/ANNUAL\%20REPORT\%202012\%20-\%202013.pdf (accessed 28 July 2014).

Prisons lack proper HIV/Aids care. http://www.enca.com/south-africa/prisons-lack-proper-hivaidscare (accessed 26 January 2014).

12. Best served with olive oil: Gitmo staffer describes force feeding to RT. 31 October 2013. http://rt.com/ news/guantanamo-force-feeding--013/ (accessed 21 February 2014).

13. Winerip M, Schwirtz M. Rikers: Where mental illness meets brutality in jail. New York Times 2014; 14 July. http://www.nytimes.com/2014/07/14/nyregion/rikers-study-finds-prisoners-injured-by-employees.

14. McMillan C. What I saw on Rikers Island. New York Times 2014; 23 July. http://www.nytimes. com/2014/07/24/opinion/cecily-mcmillan-on-brutality-and-humiliation-on-rikers-island.html?_r=0 (accessed 28 July 2014)

15. Grady D, Carey B. Medical ethics have been violated at detention sites, a new report says. New York Times 2013; 4 November. http://www.nytimes.com/2013/11/05/health/medical-ethics-violated-at detention-sites-group-says.html?pagewanted=all (accessed 3 August 2014).

16. Correctional Services 2010/11 Annual Report: Input by Civil Society Prison Reform Initiative, Judicial Inspectorate, NICRO, Auditor-General, Parliamentary Researcher. http://www.pmg.org.za/ print/report/20111011-department-correctional-services-2011-budgetary-review-committees-res (accessed 26 January 2014).

17. Precense C. Uprisings as inmates' frustration increases. Cape Times 2013; 2 October: p. 7.

18. Fokazi S. Shocking new stats on police brutality. Cape Times 2013; 27 March: p. 11.

19. Ndendze B. Striking commonality between Biko's SA in 1977 and today says Zille. Cape Times 2013, 6 September: p. 4.

20. Van Niekerk JP. Lock up and stay: South Africa’s sick prisons. S Afr Med J 2005;95(5):281

21. Habib A. South Africa’s Suspended Revolution: Hopes and Prospects. Johannesburg: Wits University Press, 2013.

S Afr Med J 2014;104(9):613-614. DOI:10.7196/SAMJ.8608 